\title{
TOT DANKSEGGING GEROEP
}

By hierdie geleentheid kom ons as gelowiges saam, om uiting te gee aan ons dankbaarheid vir wat ontvang is oor die eerste eeu wat verby is. $U$ verwag dat ek in hierdie rede $u$ gedagtes moet lei tot die inhoud, die saamgevatte kern en die seën wat ontvang is uit die Teologiese Skool en sy uitgegroeide literariese afdeling wat nou sy finale beslag gekry het in die Potchefstroomse Universiteit vir Christelike Hoër Onderwys. Dit alles stem ons dankbaar.

Vir albei hierdie inrigtings is ons dankbaar. Hulle moet gewaardeer word as ons eie, waarsonder ons nie kon klaarkom nie en dit is ondenkbaar dat ons ooit in die toekoms sonder hierdie twee inrigtings vir hoër onderwys sal kan wees. Dit is miskien die beste toets, as ons albei wegdink en dan vra: wat het ons nou tog verloor?

In ons dankbaarheid styg ons gedagtes op tot God, die Allerhoogste. Ons sien nie in die eerste plek mense raak nie, maar net God wat mense as sy instrumente gebruik, die regte mense roep en hulle begenadig met insig, geloof, toewyding, selfopoffering, geestelike balans - kortom alles wat nodig is by so 'n beginpunt. Ons bely ootmoedig: God het laat begin en het hegte grondslag laat lê. Slegs deur Gods Gees het die ingewing gekom en is ook die beginjare en 'n eeu se verloop oor moeilike tye gewil en bewerkstellig. Ek roep u tot danksegging jeens hierdie wonder van genade, wat vandag elkeen verstom laat staan. Werklik, mensehande wat moes steun, was gans te min. Mensemiddels wat die weg moes bekostig, was veels te weinig. Mensewaarborge vir die ideaal wat gekoester was sou niks anders as 'n sandhoop wees wat sou verskuif onder die fondamente en alles in duie laat stort het. Nie deur krag of geweld nie, nie deur ons talente of organisasievermoë het dit gekom nie, want alles het 'n bo-tydelike kenmerk. Ek is stom, sê die Psalmis. Ek sal my mond nie oopmaak nie, want $U$ het dit gedoen.

By hierdie geleentheid wil ekself nie aan die woord wees nie, maar wil eintlik die gebeure van die verlede tot op die hede met u laat spreek. Ek wil probeer saamvat, toespits en 'n stemming by $u$ tuisbring wat $u$ eie gevoel van dankbaarheid kan vertolk. Ons moet dit almal weer vir 'n oomblik saam beleef. 
Nou weet ek wel dat ons in die geskiedenis nie kan rondwandel sonder om sekere name te noem van persone wat God gebruik het nie, maar dan moet hierdie persone ons ook net tot danksegging roep teenoor God wat hulle in 'n sekere tyd wou gebruik.

Dit is goed dat ons in Potchefstroom vergader om feestelik hierdie eerste eeuwenteling te gedenk en dit is ook merkwaardig geskik dat in die afgelope vier dekades hier so 'n magtige uitbreiding gekom het, anders sou ons dankbaarheid darem nie so 'n hoë vlug kon neem nie. Van Burgersdorp se dae af, daardie klein begin, het die Teologiese Skool sy vierde, en telkens groter gebou, betrek; het die Universiteit uit die gesamentlike gedeelde buitekamers ook al 'n viertal persele gebruik in Potchefstroom. Maar vandag kan ons waarlik dankbaar ons medestanders rondwys en as gevolg van al die grootse bouwerke uitroep: Si monumentum requiris, circumspice. As jy 'n monument soek, kyk rondom jou.

Nou wil ek u gedagtes lei deur die geskiedenis en dit saamvat in drie woorde.

1. Die wagters

2. Die wagpos.

3. Die wagwoord.

\section{Wagters}

En by die Teologiese Skool dink ons hier aan profete wat die wag moes hou oor die kerk en suiwer die Woord moes spreek tot behoud van die volk.

$\mathrm{U}$ weet, ons kan ons baie moeilik in die omstandighede indink rondom 1859 en 1869. Kaapland was miskien darem al 'n bewoonde wêreld, waar die spore van beskawing al plaaspaaie oopgetrap het, waar bewegings oor lang afstande darem al moontlik was. Meer na die Noorde was daar nie eers sprake van dowwe paaie nie, maar slegs wielspore oor digte struikgewas wat 'n paar keer darem al bereis is, en vir die volgende aankomelinge net ' $n$ aanduiding was dat hier darem al vantevore mense beweeg het.

Dis juis in hierdie Noorde waar die begeerte opkom om ' $n$ wagter te mag bekom wat hulle in alle waarheid moet lei. Daar is nie gedink aan die onmoontlike eis wat gestel word aan 'n predikant uit Nederland, wat na 'n onbekende, wilde, totaal ongerieflike oord oor sesduisend myl moet kom nie. Gelowig 
is aanvaar dat God aan hulle 'n wagter sal gee, wat Hyself verkies, wat bereid sal wees om te kom. Hulle is nie beskaam nie, want ds. Dirk Postma het nie net gekom nie, maar was bereid om te bly, selfs nadat sy mandaat vervul is. Hy was bereid om die bande met sy eie vaderland te verbreek en in hierdie onherbergsame wêreld te kom werk. 'n Wagter, wat bekoor is deur die gedagte dat hy hier dienskneg kan wees van die Here. Hy gee homself heeltemal vir die bediening. En nie net homself het hy gegee nie, maar hy het sy hele gesin geĩnspireer om soos hy, ook hulle kragte in te span. In sy persoon is hy begenadig geword om die geestelike behoefte van die bevolking te beliggaam, te vergestalt. Hy het geëis dat sy seuns ook kerklik moes dink, bereid moet wees om hulle as wagters te laat oplei.

Skole was daar maar min en ouers het nie daaraan gedink om hul kinders gevorderde onderwys te laat geniet nie. Daarvan kan 'n kerk nie leef nie. Ds. Dirk Postma het gepleit om jongmanne wat hulle moet aanmeld vir voortgesette onderwys. Ons weet hoe hy, voor die begin van die skool in Burgersdorp, gedurende sy reise met opleiding besig was. Daar moet wagters kom oor die kerk en die groot behoefte was predikante. Uit Nederland kom daar maar nie hulp nie, net nog maar een, ds. J. Beyer, wat ook maar gou weer terug is.

Die eie kinders van ds. Postma word gestuur, gerig op duidelike bane, om te voorsien in die dringende behoeftes. Daarom lees ons van hierdie familie so baie in die eerste periode. Daarin moet ons slegs lees van dienswilligheid. Daar was die seuns P. Postma, M. Postma, S. Postma en dan die kleinseuns D. Postma jnr. en F. Postma. Laat ons maar hier ook noem die skoonseuns prof. Jan Lion-Cachet, prof. J. D. du Toit, prof. J. A. du Plessis.

Wagters, en al was hulle nie almal geskool in die volle teologiese wetenskap nie, dan het hulle tog Gods Woord besonder goed geken. Daar was wel 'n aansluitingspunt. Wêreldwys was daardie eerste wagters bepaald nie, hoewel daar al heel vroeg nogal hoë eise gestel is. Ds. P. Postma vertel dat sy vader in die heel vroegste stadium van die Teologiese Skool, toe dit nog op wiele was, aan die studente onderrig in Latyn gegee het as voorbereiding vir hulle teologiese studie. Op die Sinode van 1876 het ds. Dirk Postma die wens uitgespreek dat studente aangemoedig moet word om eers hul B.A. af te 
lê voordat met die teologiese studie begin word.

Hierdie geskiedkundige feite gee ons 'n beeld van die erns en toewyding wat daar was. In ons dankbaarheid oor die eerste wagters oor die Gereformeerde Kerk moet ons wel besef dat die Teologiese Skool ook by die vroeë begin nie die kenmerk in sy wetenskaplike vorming vertoon het van 'n goedkoop basaaragtige rommelskool nie. Daar is hard gewerk, en ons vermeld alleen hierdie feit wat getuig van die kwaliteit van die werk, dat in 'n bepaalde jaar 'n kandidaat van hierdie skool in die hele Suid-Afrika die hoogste op die lys van geslaagde kandidate gestaan het in 'n publieke eksamen vir die B.A.-graad.

Nou wil 'n mens nie die wagter Dirk Postma se plek oorbenadruk nie, maar dat hy gelei is om dadelik by kerklike meerdere vergaderings die behoefte te stel aan bediening was seker die vernaamste wat aanleiding tot die vroeë stigting van die Teologiese Skool gegee het.

Daar is eers deeglik oorweging gegee aan talle moontlikhede, veral oor die opleiding van predikante. Dit tog was die brandendste noodsaak. Nederland kon die opleiding gee en op veel bekwamer wyse as wat dit ooit hier kon geskied. Van ons Afrikaanse seuns kon ons dan daarheen stuur en weer terug ontvang as wagters in diens van die kerk. Daar is egter 'n vername rede waarom dit nie aanbeveel kon word nie. Die Gereformeerde Kerk hier te lande het dan geen seggenskap oor die opleiding nie en moet dan maar eintlik ontvang wat kom. In Europa was daar juis destyds vreemde strominge wat onrus in die kerke gegee het, en wat heel maklik oorgeplant kon word in eie kerklike kring. Hierdie bekommernis lees ons in die woorde van ds. L. J. du Plessis, wat as voorsitter van die Kuratorium die rede gehou het by die plegtige installasie van prof. Dirk Postma: „Veel is er noodig voor onze kerk, om bij de zuiverheid van de leer des Bijbels bewaard te blijven. En in vele opzichten is het zeker het veiligst, dat zij hare eigene opleiding hebbe, dat hare bedienaren, als zonen in haren schoot worden opgevoed".

Om twee baie duidelike redes is hierdie stelling gemaak. Die eerste is seker net so belangrik as die tweede. Ten eerste is besef dat as predikante sou oorkom uit Nederland, en daarop is die oog tog werklik gerig, sulke persone tog nie in die eerste plek oorkom as geleerdes, bekwame teoloë, opgelei in die 
allerbeste akademies nie. Hulle is in die eerste plek mense en dan sodanige mense wat totaal vreemd staan teenoor die mense in Suider-Afrika wat 'n heeltemal vreemde lewenswyse moes voer. Die harde skool en trekboere, ver van alle geriewe van skool, kerk, dorpe met voorsiening in noodsaaklike behoeftes, het 'n indruk gelaat op die lewe. Die wagter sou vreemd staan teenoor die kudde, sou in pastorale werk 'n groot agterstand hê. 'n Mens sou dit byna nie kon verwag dat beroepe oorweeg sou word nie. Laat ons maar duidelik sê dat daar nie baie Dirk Postmas was wat werklik deur God afgesonder is om so 'n werk in die vreemde te kom doen nie.

Maar die tweede rede is tog werklik swaarwigtig. Ons hoor so dikwels van die gevare wat op akademiese gebied ingevoer kan word uit universiteite en skole en wat dan 'n suurdeeg kan word om die hele deeg te deurtrek. Ons moet nie dink dat hierdie afgeleë deel van die wêreld so afgeskei was dat daar nie gevare kon dreig nie. Het die begeerte na wagters, predikante van 'n sekere kaliber, met 'n bepaalde Skriftuurlike verbondenheid, wat in leer, diens en tug stam uit 'n duidelike Gereformeerde atmosfeer soos wat in die Sinode van Dordrecht $1618 / 19$ vasgelê is, dan nie juis gespruit uit die wete dat die kerkgeskiedenis in die eie vaderland rooi flikkerligte laat sien wat gevaartekens is nie? Was daar dan nie rede tot kommer nie, as rewolusionêre dryfkragte in Europa 'n heersende invloed bekom het en die geeslose rasionalisme wat 'n tydlank bekoor het, vervang is deur 'n oppervlakkige mistisisme, 'n opstuwende emosionalisme, wat gelei het tot 'n soetsappige metodisme?

Prof. J. D. du Toit het nie verniet as tema vir sy proefskrif vir die dogtorsgraad „Het Methodisme" geneem nie. Dit was 'n aaklige spook wat die kerklike lewe helder bedags deurwandel het en die aanslag op die hart van die Gereformeerde Kerk is hom gespaar geword juis omdat hy hom tydig afgeskei het. God het heldersiende wagters beskik wat van die begin af ons gelei het op baie veilige weë. En so was hierdie klein begin werklik een wat in die kerklike lewe 'n duidelike klank laat hoor het. Die kerk het nie net self gespaar gebly nie, maar kon ook 'n roepstem vir ander kerke wees om tog nie hulself oor te gee aan hierdie soetklinkende sirenesang nie. Die beste middel teen sulke aweregse rigtings is tog om die kleinste worteltjies uit eie liggaam voortdurend versigtig uit te skoffel.

Ek vermoei u nie met die noem van al die name van pre- 
dikante wat van die begin af aan die herderstaf gedra het nie. Dit is genoeg as gesê word dat die oog gerig was op die behoefte aan wagters oor Gods kerk wat hier tot openbaring gekom het. Dit was die eerste oogmerk en vernaamste dryfkrag om te kom tot skooloprigting. Sindsdien het daar na die eis van die tye telkens weer manne gekom wat die geledere versterk het. Sinds die oprigting van die Teologiese Skool in 1869 is daar 298 predikante afgestudeer en die lidmatetal het gegroei van 'n eerste vyftiental tot 102,000 , en 25,000 nie-blankes. Die menseaandeel hieraan is alleen maar in sover God hulle geroep en bekwaam het om wagters te wees oor sy kudde. En ons word tot danksegging geroep.

\section{Die wagpos}

In die Skrif het die profeet 'n wagpos gehad waarop hy moet staan en wat hy nie mag verlaat nie. Hy was die brandwag oor 'n volk waaroor hy wagstaan en hy moes met 'n skerpsiende oog die omgewing bespied om tydig die basuin te blaas as daar vyandelike magte mag nader. Daarom was sy wagpos hoog op 'n muur wat die stad omring.

Aan Jesaja word gesê: „Sit 'n wag uit; laat hom te kenne gee wat hy sien; en sien hy 'n stoet ruiters, twee aan twee, 'n stoet esels, 'n stoet kamele, dan moet hy skerp luister, so skerp as hy kan".

En dan hoor ons: „Op die wagtoring, Here, staan ek gedurig by dag, en op my wagpos stel ek my al die nagte" (Jes. 21).

'n Swaar verantwoordelikheid, want die veiligheid van almal in die stad is van hom afhanklik. In Eseg. 3 hoor ons: „Mensekind, Ek het jou as wag vir die huis van Israel aangestel; en as $\mathrm{jy}$ 'n woord uit my mond hoor, moet jy hulle van my kant waarsku. As Ek aan die goddelose sê: ,Jy sal sekerlik sterwe' - en jy waarsku hom nie en spreek nie om die goddelose in sy goddelose weg te waarsku om hom in die lewe te hou nie, dan sal hy, die goddelose, deur sy ongeregtigheid sterwe; maar sy bloed sal Ek van jou hand eis".

Gods wagters wat Gods wil moet aflees en verkondig, was begaafde, oorgegewe, geloofsbewuste, gewillige instrumente, wat soms eeue vooruit kon sien en tydig Gods Woord uitroep.

$\mathrm{U}$ moet wel begryp dat die wagpos nie op die tempelterrein was nie, maar op die stadsmuur, en hierdie muur sluit sowel die tempel as die volk in. Dit is belangrik, want God wil sy 
oog laat gaan oor kerk en volk, want 'n kerk staan midde in die volk. As Esra terugkom uit die ballingskap, begin hy met die tempel te herstel. Dan kom Nehemia en vestig die oog op die stadsmuur wat heeltemal vervalle is en begin dit te herbou. Sekerlik, 'n kerk moet mure rondom hom hê, maar 'n volk moet ook afgegrens word, moet ook nie maar na alkante toe 'n oop skyf wees vir geestelike erosie en verwaarlosing nie. Die wag. pos op die stadsmuur sê: Laat Gods Woord hoor oor die hele volk en sluit die hele volk in binne die grense van die Godsopenbaring.

Vir ons feesvierende het hierdie feite ook 'n boodskap. Aan die beginners van hierdie werk is dit gegee om die eerste boustene aan te dra vir 'n teologiese skool en 'n universiteit. Hulle kon die oog maar net gerig het op die onmiddellike dringende behoeftes van hierdie oomblik. Die begin was egter nie so nie. Die Skool moes nie maar net 'n funksie vervul wat voor-die-hand-liggend was nie, maar dit moes sy taak duideliker in die oog vat. Dit is waar: die eerste behoefte was dat die Gereformeerde Kerk predikante nodig het om hom te bedien. Nederland kon nie voorsien nie. Uit ander oorde kon daar miskien voorsiening kom, maar is die wagpos dan goed beman? 'n Kerk kan tog nie die belangrike roeping toevertrou aan persone wat hy maar moet ontvang en moet gebruik nie. 'n Kerk moet tog kontrole hê oor die opleiding en die opleidingsentrum moet onverdag wees, anders word 'n vreemde leer binnegenooi. Dit baat dan nie om 'n muur te hê, maar jou wagter bo-op die muur kan die vyand nie skerp onderskei nie.

Ons weet dat Skotse predikante ingekom het, maar saam met hulle het daar ook 'n geestesrigting gekom wat vreemd was. Ons weet dat daar met 'n noukeurige en onderskeidende oog die teologiese en volkekundige rigting ontleed moes word.

Ons mag miskien dink dat die suiwerheid van die kerk veel meer op die voorgrond gestaan het as die wesensmatige eiendomlikheid van die volk, maar so sê die geskiedenis nie. Liefde in die kerk is juis liefde vir die volk. Dit is werklik die brandende liefde vir volksbehoud binne 'n beginselvaste bely. denis, wat besiel. Die muur rondom die volk en sy kerk spreek duidelik.

Daarom sien ons dat hierdie stigters nie net die kerk nie, maar die Afrikaanse volk raak gesien het. Daar is met 'n ontledende oog 'n diagnose gemaak van die volksbehoeftes. Daar 
is gevind dat daar skole moet wees wat by die ouers se belydenis moet aanpas. Skole, Christelike skole, moet aan ons kinders gegee word. Dit hierdie kinders wat juis deur die bemoeiing van die kerk ingesluit moet word binne die muur. Die muur is vandag tog nie meer ' $n$ klipmuur van steen en beton nie. Dit is veel meer as dit - dit is die afgrensende beginsels, die geestelike erfenis van Gods Woord. Dit is Gods Gees wat deur Gods Woord ' $n$ vurige muur rondom die volksjeug moet wees.

'n Mens mag mos nie maar almal insluit binne die muur en naderhand vind dat jy euwele elemente daarbinne het wat nie daar behoort nie.

Daarom was die Teologiese Skool so 'n duidelike klank oor die breë volksakker. Dit het 'n duidelike sinjaal gegee vir die onderwys. Geen wonder dat uit hierdie kring die stryd gevoer is, nie maar vir die skool nie, maar vir so 'n skool, vir die regte skool, die Christelik-Nasionale Skool. Vir ons kinders net die beste. Dan kan hierdie kinders roepingsbewus voorberei word vir hul roeping.

Die hele volksakker moet bedien word. Daar is geleerdes nodig in staatsposisies, kundiges as prokureurs om advies te gee en die sake te behartig. Suid-Afrika lê braak, en as iemand die leiding in eie omgewing wil neem, moet hy nie net 'n goeie insig hê nie, maar geslypte vermoëns. Daar is so baie vreemdelinge wat die land binnekom en vanweë kundigheid die land uitbuit in eie belang. Vreemdelinge kan tog nie liefde vir die volk hê nie en sien eie optrede nie as diens aan die land nie.

As ons slegs maar ons kan inleef in dieselfde toestande net maar kan besef dat veral die Noordelike dele van ons vaderland eintlik niks meer as voortrekkerland was nie - besef ons terdeë dat hier 'n hart oopgaan in liefde vir die land en volk. Dit gaan om die landskind, die dienswilliges wat die posisie in staat, skool, maatskappy moet beman; uit liefde vir die medevolksgenoot en ware patriotisme hulself ten volle te gee.

So moet ons die begin sien. Dit gaan om 'n kerk en predikante vir die kerk. Maar grootser, hoër, wyer: dit moet 'n skool wees wat ook die volk wil dien.

Ek pretendeer nie te veel nie.

Uit 'n redevoering van prof. Jan Lion-Cachet wat hy gehou het by die 20-jarige herdenking van die bestaan van die skool, haal ek die volgende aan. Hy vra die gerigte vraag: Het die 
Teologiese Skool en sy literariese afdeling aan sy roeping beantwoord? Hy oordeel dat daar altyd gestreef is na 'n hoër graad van wetenskaplike opleiding. Wat regsinnigheid betref is die skool na 20 jaar nog net so regsinnig en net so nasionaal as aan die begin. Daar word wel geklaag dat daar so min jongmanne hulle aanmeld vir verdere onderrig. „Zullen de Afrikaners in den strijd der nationaliteiten blijven bestaan, dat wil zeggen, zullen zij den rang en stand behouden die hun toekomt, dan moet er meer en beter onderwijs genoten worden". Prof Cachet benadruk nou nie meer soseer die behoefte van die kerk aan predikante nie. Hy sê: „In de eerste behoefte der kerk is voorzien, aan leeraren is geen gebrek: maar de behoefte aan onderwijs is toegenomen. Ik herhaal het: zullen de Afrikaners blijven bestaan, dan moeten onze zonen altijd meer en meer in staat zijn om de voornaamste plaatsen te bezetten. Zij moeten het land besturen en verdedigen".

Groots is die gedagte en breed die visie.

Dit sou geensins bevreemd as die doel slegs sou wees om die kerk te dien en predikante op te lei nie.

Nee - sy opvoedende krag en vormende waarde het meer in die oog. In die eenvoudige woorde van prof. Cachet heet dit: "Wij wenschen algemeen nuttig te zijn". En dit was nie maar 'n praktiese beleid nie, maar 'n vaste beginselgrondslag. Immers die Gereformeerde Kerk het nog nooit die standpunt aanvaar dat die kerk soos 'n oliedruppel moes dryf op die waters van die volkslewe nie. Daarom mag die kerk nie van die volkslewe losgemaak word nie, maar moes in die innigste verband daarmee staan. Daarom is dit asof die Gereformeerde Kerk intuittief aangevoel het wat die nasionale koers moes wees, en die manne het 'n leidende aandeel geneem in die verwerkliking van daardie koers. Dit is immers nie vreemd dat Cachet een van die leiers was van die eerste Taalbeweging nie en dat Totius weer 'n stoot aan die Tweede Taalbeweging gegee het nie. Dit is ook nie 'n wonder dat die taalmonument op Burgersdorp staan nie en dat die koers na 'n selfstandige republiek as staatsvorm in hierdie kring sy kampvegters gehad het nie.

'n Skool ten dienste van die vaderland, vir die hele SuidAfrika - en die Skool bly maar klein.

Na 20 jaar rapporteer die rektor: Tot op hede was daar 47 studente aan die skool ingeskryf oor die 20 jaar heen. Twaalf het predikante geword, 5 onderwysers en 3 prokureurs. 
U kan wel begryp dat prof. Cachet dit só uitgedruk het: Ek durf dit eintlik nie hardop sê nie, uit vrees dat daar 'n glimlag op u lippe sal kom, maar fluister wil ek dit tog, dat ons van die begin af gedink het aan ' $n$ Christelike Universiteit. Ons het begin om 'n fondament te grawe in die hoop dat eenmaal op daardie fondament 'n tempel van wetenskap sou verrys waarvan die hoeksteen sou wees Gods heilige Woord.

Dit was werklik profetiese woorde.

As ons tot danksegging geroep word, is dit sekerlik rede tot danksegging: dat van die begin af nie 'n eng kerklike standpunt ingeneem is nie, maar met Gereformeerd het hulle die patroon bedoel en gevolg van die Christelike, nader Calvinistiese, lewens- en wêreldbeskouing.

As ek $\mathrm{u}$ tot danksegging roep, moet ons rondom ons heenkyk en sien hoe God die insigte, die idees, die grootse konsepsies geseën het, want alles rondom $u$ getuig daarvan. Die kerk het wel die inisiatief geneem, maar dis tog waar dat die dogter van die Teologiese Skool en daarmee bedoel ons die Potchefstroomse Universiteit vir Christelike Hoër Onderwys, besonder vinnig gegroei het in die afgelope 30 jaar. Nou tel ons ons studente nie meer in 'n paar tientalle oor 'n paar tientalle jare nie, maar by hul duisendende in een enkele jaar. Geen duideliker teken is daar vir die gewildheid van sy rigting en die dienstigheid van sy opset nie, as dat studente oor die hele Suid. Afrika juis hierheen kom om wetenskaplik gevorm te word. Natuurlik is die wetenskaplike onderrig van die beste en behoort dit Gods diepe gedagtes na te vors. Maar wat ons ook tot danksegging roep is dat ons nog steeds die prinsipiële koers volg en daar jaloers op is. Die Calvinistiese, of wil u: die Skrifgebonde lewens- en wêreldbeskouing is 'n sieraad wat aan die nageslagte deurgegee moet word. Die betekenis daarvan kan nie maklik in woorde uitgedruk word nie, want dit is sedelik-geestelik van aard. Dis soos 'n suurdeeg wat deurwerk, en sy werking kan nie gesien word nie, maar tog ervaar word, omdat dit juis die suurdeeg is wat die deeg tot brood maak. Dit moet bly deurwerk in ons persoonlike, gesins-, skool- en volkslewe. Dis die muur rondom die volk.

\section{Die wagwoord}

Was die wagter en die wagpos al belangrik, veel belangriker is die wagwoord. 
U kan dit goed begryp, want dit is die wagwoord wat die wagpos en wagter belangrik maak. Stel $\mathbf{u}$ voor dat die profeet op die wagpos staan, maar hy het nie 'n woord nie - of erger nog: hy laat 'n verkeerde woord hoor wat gerusstel in plaas van wakker te roep en 'n volk op sy hoede te plaas. Dit sou 'n profeet sonder basuin wees, of 'n basuin met 'n vals klank, wat die sielsroersele met sy gesketter pynig.

Van die begin af is die wetenskaplike navorsing van Gods Woord en sy betekenis vir alle wetenskappe as mikpunt daargestel.

Prof. S. Postma vat dit mooi saam in sy inougurele rede. „Het beste wapen om de verkeerde en verderflijke richtingen, de valsche wetenschap en de ijdele philosophie te bestrijden, is de wetenschap zelve. Onder het zwaard van Goliath valt zijn eigen hoofd het gemakkelijkst. Hiermede willen wij zeggen dat de opleiding van de toekomstige leeraren zijn moet naar de eisch des tijds. Hij moet op de hoogte van zijn tijd zijn en bekwaam wezen zich met gemakkelijkheid en overeenkomstig de waardigheid van zijn ambt overal te bewegen. De wetenschap moet gemaakt worden de dienares van het Christendom".

Toespitsing op die wetenskaplike benadering is ' $n$ verpligting, as die nuwe ideale van 'n groot universiteit tot werklikheid moet kom. En vir die wagwoord wat geproklameer moet word, is dit seker 'n verpligting, want alleen so kan 'n suiwer geluid gehoor word. Op elke gebied van die wetenskap moet dit waar wees. Wie mee wil spreek op hierdie gebied, op akademiese erf, moet eers navors, verifieer en sistematiseer en daarna publiseer en spreek. Dit is waar dat ons nie die waarheid soek nie, omdat ons Hom het: Jesus Christus wat aan ons as Gods waarheid gegee is en gesê het: Ek is die waarheid. Ons moet die waarheid ondersoek uitgaande van ons besit, en dan breek God alle beletsels voor ons af, veral sondebeletsels. Hoe sal ons ooit anders by Christus kom, ons wat so bedorwe is, so blind en jammerlik, so verskeurd en verdonker? Uit onsself kan ons nooit tot die waarheid kom nie. Maar nou dat Hy aan ons gegee is, en aan ons ook die Heilige Gees gegee is; nou dat ons begenadig is en ingewortel, ingelyf, ingebou is in Christus; nou dat ons vernuut is en Gods lig in ons ontsteek is, kan ons met vertroue op die pad van wetenskaplike ondersoek gaan.

Die wagwoord is Christus, die vleesgeworde Woord. 
Die wagwoord is Gods Woord wat van begin tot einde spreek van Christus. Dit is die Geesteswoord wat ons verstand verlig en ons hart vreugde gee.

Uit die predikantenood of liewer bedieningsnood, is die Teologiese Skool en die Universiteit gebore. Uit die kerk se nood is die gedagtes gevoer na die noodsaaklikheid, die onkeerbare dors na kennis en wetenskap, eers oor die Skrif en dan ook oor die terrein van Gods hele skepping. Teologiese besinning en wetenskapsbeoefening oor die verdere gebiede moes bring tot die totstandkoming van die Universiteit. En as dit waar is dat waarheid altyd as waarheid gehuldig moet word; as dit waar is dat iemand wat 'n brokstukwaarheid opnuut in sy regte perspektief gesien het dit nie vir homself kan hou nie, kan $u$ begryp dat die Universiteit gou groter en groter geword het. Die rede is eenvoudig: die ondersoek na die waarheid verryk nie net die ondersoeker nie, maar inspireer ook die student. Die taak en doel van die Universiteit is nie net maar 'n skoolklaskamer te wees en die kennis van die verlede oor te dra aan studente om hulle so te bring by die goudmyn en alle werk daar te toon nie. Die taak is seker om hulle tot deelname in die ontginning te verplig - om die lus tot studie tuis te bring, om dit aan te wakker en die program vir die toekoms daar te stel. Daarom is tereg gesê dat 'n universiteit moet drie take bly verrig: dit moet conservatorium wees, om alle kennis te versamel en getrou te bewaar. Dit is al 'n groot taak, want die geskiedenis van elke wetenskap bied al 'n groot skat en ook waarskuwingstekens vir die komende garde. Die Universiteit moet ook 'n observatorium wees, wat met besieling alles bekyk, opnuut bekyk; wat Gods Woord beluister en opnuut beluister en dankbaar bly dat deur gelowige onderworpenheid daar steeds tot diepere dieptes gekom kan word. Ek het gepraat van 'n goudmyn en die word al dieper, totdat dit sy beperking stel en die delwer nie dieper kan kom nie. Dan moet nuwe ontdekkings kom en metodes, en dan gaan dit nog dieper en dieper. Daar is geen einde nie. Ons mag nie ophou om observatorium te wees nie, nie op enige gebied van die wetenskap nie. Dit is 'n wêreld wat nog steeds sy dieptes ontvou, nog steeds sy bekoring behou. En ten derde moet die Universiteit laboratorium wees, nie in die gewone sin van die woord, dat dit maar net beperk is tot sekere natuurwetenskappe nie. Dit beteken net dat elke wetenskap ' $n$ werkplek is, 'n plek van inspanning, 'n 
plek waar met alle krag gekonsentreer word op dit wat elke wetenskaplike meen om te ondersoek. Harde werk vir die navorser is 'n eis. Dis dikwels ' $n$ eensame taak wat met veel opoffering gepaard gaan. Veel moet prysgegee word en daar is geen bepaalde werkuur nie.

Universiteitswerk is, soos A. Kuyper dit uitgedruk het, soos wanneer die bergklimmer die bergtoppe bestyg. Dis swaar werk en moet versigtig aangepak word. Ons kom dan bo. Dis daar eensaam en koud. Maar daar is ' $n$ vaste wete: as die sneeu smelt, loop die water langs berghange af om die laagtes onder te bevogtig en lewe te bring vir dor velde wat daarop wag. Dis harde werk om berge te bemeester, maar dis 'n vreugde om maar steeds inspannend te styg in die wete dat ons meer en meer bereik.

So staan die Teologiese Skool en die Universiteit binne-in die volkslewe. Dis bepaald daarom dat ons Teologiese Skool en Universiteit so 'n eie plek het in ons harte. Ek noem nou albei in eén asem, omdat hulle saam behoort. Met die opening van die Teologiese Skool op Potchefstroom in 1905 het ds. P. Postma dit só uitgedruk: „De stichter der Kerk voelde dadelijk de behoefte van een literarisch departement naast het theologische. Het Gereformeerd beginsel moet heel de wetenschap beheerschen en bevruchten. Onze jonge mannen die in andere vakken dan de theologische studeeren moeten onder invloed van dat beginsel opgeleid worden".

Dit was noodsaaklik om die hele opleiding in alle weten. skappe te bind aan ' $n$ bepaalde geloofstandpunt. Ons weet dat dit hier gaan om die wagwoord wat oor 'n volk as 'n werdaroep hom waaksaam moet hou. Die Teologiese Skool kan net éen fondament hê, nl. die konfessionele uitgangspunt van die kerk wat hy moet dien. Maar toe besef is dat dieselfde konfessionele standpunt 'n bolwerk moet wees vir die handhawing en voortplanting van 'n suiwer wetenskaplike siening op elke terrein, en dat dit eintlik meer bied as enige ander wyse van weten. skapsbeoefening vanweë sy aanvaarding van Gods Woord ook as inhoudelike kennisbron, is hier standpunt ingeneem wat nog altyd met groot vrug ons volk dien. Die band aan Gods Woord moet tog seker nie al losser gemaak word soos die verderflike liberalisme wil nie. En as ons vandag die sirenesang nog hoor dat ons ons nie die nadruk moet lê op die leer nie maar op die lewe; nie op die prinsipiële nie maar op die eksperimentele, 
is dit die teken vir ons om des te vaster te staan by die beginsels wat tog die diepste, die ewige gronde is vir alle wetenskaplike navorsing. Leervastheid beteken tog bepaald nie ortodoksisme en stilstand nie. Inteendeel, dit is die roeping tot progressiwiteit en tegelyk koersvastheid in die progressie. Dit is juis die beginselvastheid wat 'n kenmerkende invloed uitoefen op ons wetenskapsbeoefening, want dit maan tot versigtigheid, tot verantwoordelikheid en vrywaar van oorhaastige beslissings, ontoereikend-gemotiveerde konklusies en dus wetenskaplike foute wat voorkom kon gewees het. Die Christen-wetenskaplike is hierdie versigtigheid nie net aan homself verskuldig nie, maar ook aan diegene wat saam met hom op dieselfde prinsipiële grondslag staan. Dit is nie net 'n samewerking tussen Gereformeerde of Skrifgebonde wetenskaplikes wat ons hier bepleit nie. Dit gaan nie maar net om onderlinge bevrugting en sanering nie. Dit gaan veel verder as wat ons gewoonlik ons bewus van is. Die Universiteit en sy wetenskaplikes staan nie los van 'n groot volksdeel wat met hom op dieselfde prinsipiële grondslag staan nie. Die Teologiese Skool is hom natuurlik veel meer daarvan bewus, omdat hy predikante oplei vir die kerk, vir die volksdeel wat in hul belydenis aan die bepaalde kerk verbind is. Vir die Gereformeerde volksdeel is dit 'n regmatige eis dat hulle voorgangers betroubare manne moet wees, want Gods Woord moet aan hulle rigting gee, moet die geloof versterk. Prof. Dirk Postma het eintlik die naarstigheid na suiwerheid by die opvattinge oor Gods Woord as eerste eis gestel, toe hy gesê het dat 'n onsuiwere Skrifverklaring groter skade kan doen as die slanggif van die giftigste adder. Maar dit geld ook van die professore en lektore van die Universiteit. $\mathrm{U}$ moet tog nie dink dat $\mathrm{u}$ met $\mathrm{u}$ wetenskaplike resultate die gelowige volksdeel maar straffeloos kan skud en skok nie. $\mathrm{U}$ is nie ' $\mathrm{n}$ afgeslote kring van beoefenaars van wetenskap wat maar net vakarbeid verrig en slegs aan die wetenskaplikheid trou verskuldig is nie. Lindeboom het dit tog al só gesê: „Een Theologische wetenschap en studie met een ander voorwerp en doel dan de ware kennis en dienst van God, is dus niets anders dan werk van afgoderij, afgodendienst. Dan wordt de studie en de wetenschap zelve het doel. Dan wordt de studie... misbruikt als een middel om niet het Object, maar het subject, den mensch zelven, te eeren en, in het eind, zich stoutweg te verheffen boven God en Zijn Woord". Presies dieselfde geld 
van elk wetenskap. Elke dosent aan die Teologiese Skool en Universiteit beoefen sy wetenskap ,in U lig" en is solidêr verbind aan die Gereformeerde volksdeel, wat dankbaar is vir die vordering wat op wetenskaplike gebied deur sy eie Universiteit, waaraan hy geloofsverbonde is, gemaak word. Die Teologiese Skool en Universiteit het albei daadwerklik met Gods Woord te doen, en hierdie twee inrigtings is juis tot stand gebring deur geletterdes en ongeletterdes, deur samewerking van baie eenvoudige gelowige mense, en die welsyn van hierdie inrigtings is vir elkeen van hierdie mense 'n faktor van ingrypende betekenis. Vir hierdie gelowige mense is dit nie net die regmatige verlange na die suiwere Skrifuitleg nie, maar ook na onderwysers vir hul kinders wat aansluit by die huislike opvoeding; na gelowige geneeshere vir die versorging van hulle siekes, na wetenskaplikes wat koers gee op die gebied van biologiese, fisiese en chemiese vlugte van die intellek. Hier moet leiding kom op elke gebied van die geesteswetenskappe, want orals hoor ons van krisisse. Of moet die Wysbegeerte nie wagstaan, die Sielkunde nie leer, die Etiek nie weerhou, die Volkekunde nie ondersteun, die politiek nie lei nie? Te veel om op te noem. Maar dis seker genoeg om $u$ te laat verstaan dat hierdie Teologiese Skool en Universiteit, kragtens hul geboorte en voortgang oor honderd jaar 'n geliefde stuk geword het van die geestelike besit van mense wat vir hulle bid, vir hulle wil offer, en vol verwagting die oë op hulle rig en hul kinders stuur.

Dit roep ons tot danksegging.

Die besondere standpunt waarop ons staan is een wat ons bind aan 'n wagwoord, en die wagwoord is "In U lig". Gods Woord is daardie wagwoord.

En nou weet ons dat ons hier ook te doen het met 'n krisistoestand. Mense vra: weet ons vandag nog wat Gods Woord is? Het met die wêreldoorloë en die nagevolge van frustrasie en moedeloosheid nie ook gekom 'n onverskilligheid wat wel deur Gods Woord voorse is, maar nie deur Gods Woord veroorsaak of gevoed word nie? Daar is vooruitgang op elke gebied, maar veral op die gebied van die natuurwetenskappe en tegnologie. Dit is al asof parallel met die ontwikkelingsvaart ons ' $n$ verwaarlosing kry van die tradisionele opvattinge, 'n neerhaling van dit wat tot dusver gangbaar was. Dit is veral merkbaar by ons hedendaagse opvattinge oor wat die gesag van Gods Woord 
is. As iets nie nuut is nie, as gedagtes nie in 'n ander spoor gaan nie, word dit sonder verskoning verwerp. Maar is ons telkens seker dat ons op die weg van versigtigheid, verantwoordelikheid en sekerheid gaan? Moet teoloë nie veel stadiger met hul gedagtes gaan en nog langer wag voor alles gepubliseer word, totdat daar duidelikheid en volkome sekerheid is oor 'n standpunt nie?

Dit skyn asof daar met haas en spoed gewerk word, nie genoegsaam onderskeidend nie, naderhand uit pas met die historiese verloop. Dan skok dit. Dan wek dit twyfel. En as die woekerplant van twyfel eers gewortel het, word dit 'n tierende onkruid. Dit kan so maklik vertwyfeling word. Laat ons tog gewaarsku wees om nie Gods Woord te problematiseer nie, of dit geskied met 'n buiging teenoor watter wetenskap ook al, of dit nou al wysgerige strominge van eksistensialistiese allure, biologiese teorieë van ewolusionistiese of kwasi-ewolusionistiese aard, of teologiese tendense van Barthiaanse oord is.

Dit wil nie sê dat ons moet verstar nie, maar wel dat ons geen stap vorentoe neem wat nie weloorwoë is nie, veral waar dit donker is, te donker om duidelik te sien. Want as ons wagwoord nie helderklaar en duidelik is nie, gaan dit nie slegs teologiese invloed hê nie, maar sekerlik uitdy tot beînvloeding van ander wetenskappe, wat tog seker die reg het om telkens te vra: Wat se Gods Woord?

Die ontstaan van die Universiteit uit die Teologiese Skool plaas ons voor 'n geweldige opgaaf: om nooit te verstar in onwetenskaplike napratery van die verlede nie - want dit is die sekerste manier waarop die ander wetenskappe sal wegruk uit 'n knellende band wat hulle wurg. Maar ons moet ook nie net die nuwe najaag nie, want dit sal die sekerste manier wees vir die teologie en alle ander wetenskappe daarmee saam om op 'n dwaalweg te gaan, waarop die kans op terugkeer maar baie skraal is.

Totius het dekades gelede geskryf, asof dit 'n brief is aan elkeen van huidige dosente: Geagte Professore en Lektore, ek hoop dat nooit 'n student $u$ gehoorsale sal verlaat met die verwyt: „U het van my 'n twyfelaar gemaak”. Op hierdie negatiewe noot gaan ek nie afsluit nie. Daarvoor is die geleentheid te enorm groot.

Kom ons gaan met ootmoed en ook met moed, biddend die toekoms in. Kom ons trek voort met... met 'n lofpsalm 
in die hart en op ons lippe, want God het ons in die verlede so trou bewaar, op sy pad gehou, sodanig geskraag dat 'n dankbare skare ook nou saam is. Daar was donker dae. Dit het lig geword daarna. Miskien is dit nou nog donkerder dae. Daarom sal die lig des te helderder daarna wees. Daar is vertroue en die bede is dat hierdie twee inrigtings kragtig sal meehelp tot wetenskaplike frisheid. Kom ons sweer trou aan ons grondslag en bly dankbaar vir ons verlede en ons neem daaruit die goeie en skone en bou daarop ons toekoms. Kom ons bely weer saam met die Teologiese Skool se embleem: „U lig en U waarheid" en saam met die Universiteit: „In U lig”.

Mag geloof, hoop en liefde ons daarby besiel. En van die drie is die liefde die meeste. Liefde tot God wat aan ons die Skool en Universiteit geskenk het. Liefde vir hierdie eie dierbare erfenis wat God ons gegee het en wat ons roep tot offer van al ons talente en al ons gawes in diens van God en van die wetenskap. En gee God dat ons ook weet: Waar liefde woon gebied God sy seën.

Met die ou seënwens groet ons: Vivat, crescat, floreat Academia. Nostra.

P.U. vir C.H.O.

S. P. van der Walt. 